\title{
Role of Bacteria in Tempe Bitter Taste Formation: Microbiological and Molecular Biological Analysis Based on 16S rRNA Gene
}

\author{
TATI BARUS ${ }^{1}$, ANTONIUS SUWANTO ${ }^{1 *}$, ARIS TRI WAHYUDI ${ }^{1}$, AND HANNY WIJAYA² \\ ${ }^{1}$ Department of Biology, ${ }^{2}$ Department of Food Science and Technology, Institut Pertanian Bogor, \\ Darmaga Campus, Bogor 16680, Indonesia
}

\begin{abstract}
Tempe is traditional Indonesian food. It has a variety of tastes, sometimes with a hint of bitterness, which may differ in intensity. The cause of bitterness in tempe has never been reported previously. In this study, the aim is to identify whether bacteria play a role in the formation of bitter tastes in tempe. Sensory tests were carried out in order to determine the scores of bitter-taste-intensity in tempe. The sensory test on EMP, WJB, CLR, DRG, and MLB tempe shows that EMP tempe has the highest score (2.3) and WJB has the lowest (1.3). It is revealed that the processing method has no impact on the formation of the bitter taste in tempe. Plating analysis, showed that EMP soaking water contained a higher number of Enterobacteria group bacteria, approximately $10^{3}-10^{4} \mathrm{CFU} \mathrm{ml}{ }^{-1}$ and spore-forming bacteria groups, $10^{2} \mathrm{CFU} \mathrm{ml}{ }^{-1}$, compared to WJB. Similarly, other bacteria groups in fresh EMP tempe was $10^{2} \mathrm{CFU} \mathrm{g}^{-1}$ higher than those in fresh WJB tempe. Based on sequencing the16S rRNA gene, the dominant bacteria on PCA media in EMP tempe are Acetobacter indonesiensis, Klebsiella pneumoniae, Bacillus subtilis, and Flavobacterium sp. On the other hand those in WJB tempe were Klebsiella sp., Brevundimonas sp., Bacillus sp., Pseudomonas putida, and Acinetobacter sp. Bacillus, a group of proteolytic bacteria was found $10^{5} \mathrm{CFU} \mathrm{m}^{-1}$ higher in the soaking water of EMP compared to WJB. Nevertheless, the types and numbers of fungi were not significantly different between tempe types. Accordingly, it is concluded that the difference in the number and the types of bacteria involved in the tempe production process leads to the difference in the bitter taste intensity in both EMP and WJB tempe.
\end{abstract}

Key words: tempe, taste, bacteria community analysis

Tempe is a traditional food in Indonesia wich is made through a fermentation process, mainly using Rhizopus oligosporus. There are many different kinds of tempe depending on the raw material, but the most famous one is tempe with soybean as its raw material. The kind of tempe studied in this research is the soybean tempe, which in this research is defined as tempe.

Other than $R$. oligosporus, the presence of bacteria is very important in tempe production, as some of them play a role in improving the quality of tempe. For example, Citrobacter freundii and Klebsiella pneumoniae can increase the content of vitamin $B_{12}$ (Keuth and Bisping 1994), and Micrococcus or Arthrobacter play a role in the formation of isoflavones (Klus et al. 1993).

Microorganisms have been reported to play a role in flavor formation in fermented foods (Hagedorn and Kaphammer 1994). For example, bitter taste in cheese is caused by protease activity of Lactococcus lactis subsp. Lactis (Broadbent et al. 2002), the diversity of lactic acid bacteria influences wine quality (Rodas et al. 2003), and Staphylococcus xylosus affected the aroma of sausages (Stahnke1994).

The flavor of tempe is variable, but it is inconsistent and sometimes unpleasant flavors wich are not favoured by consumers. The flavor in food products is a very important factor that influences consumer's decision in their choices of food product. One of the undesirable flavors is bitterness. Bitterness is a main characteristic of fresh tempe. The intensity of bitterness in tempe can differ among producers even though they use the same raw material and inoculum (Hartoyo 1994). Although there is relatively the same fondness of the

*Corresponding author, Phone/Fax: +62-251-8315107, E-mail: asuwanto@indo.net.id taste of tempe, bitterness is not one that is favored by consumers.

Tempe is locally produced through several kinds of processing methods, generally using uncontrolled conditions. The factors causing different intensities of bitterness in tempe have not been reported so far. Therefore, the aim the study is to identify whether bacteria play a role in the formation of such bitter tastes in tempe.

\section{MATERIALS AND METHODS}

Bitterness Sensory Test. The examples of tempe were obtained from five producers in the Bogor area. Those five producers are CLR, DRG, MLB, EMP, and WJB. All five kinds of tempe were produced using the same type of soybean as raw material. Sensory test were conducted by panelists who had been selected after they went through several tests as follows: Sixty students from the department Science of Food technology, Bogor Agricultural University, were made available as panelists. Sensory sensitivity of the candidates was measured in three stages. The first stage was a matching test. Five basic tastes were selected: sour ( $0.04 \%$ citric acid), sweet $(0.7 \%$ sucrose), bitter $(0.04 \%$ caffeine), salty ( $0.2 \%$ sodium chloride), and umami ( $1 \%$ monosodium glutamate). The second step was a triangle test for bitterness (0.02 and $0.04 \%$ caffeine), and the third stage was a bitterness ranking test $(0.025,0.04,0.06$, and $0.08 \%$ caffeine). The criterion used to select panelists from every stage was those giving $80 \%$ correct answers. The selection process resulted in 13 panelists who were then trained for the bitterness test. Caffeine concentrations of 0.025 and $0.05 \%$ were used as the standard in the bitterness sensory test on tempe samples employing the rating test (Meilgaard et al. 1999). 
Fresh tempe $12 \mathrm{~cm}$ x $2 \mathrm{~cm}$ x $2 \mathrm{~cm}$ size were steamed for 15 min and then cut into $4 \mathrm{~cm} \times 2 \mathrm{~cm} \times 2 \mathrm{~cm}$ pieces before being served to panelists. Panelists were asked to determine the bitterness of tempe by comparing it to the standards provided. Bitterness intensity scores were listed between 0-5 (score 0 for the lowest bitter taste intensity and score 5 for the highest). The data were then analyzed using analysis of variance and tested further with Honestly Significance Difference (HSD). From these bitterness sensory tests, "non bitter" tempe (with the lowest intensity) and "bitter" tempe (with the highest intensity) were selected.

Tempe Production. Tempe was made using original tempe inoculum from PT Aneka Fermentasi Industri (AFI), Bandung, Indonesia, which is usually used by the WJB producer and also in the mixed tempe culture used by the EMP producer. Tempe was processed employing the WJB method (Fig 1) and the products were then subjected to the bitterness sensory test.

Fungal Analysis. Fungal analysis was conducted on "non-bitter" and "bitter" fresh tempe. The medium used was Potato Dextrose Agar (PDA) (Difco) with the addition of 0.3 g. $\mathrm{l}^{-1}(\mathrm{w} / \mathrm{v})$ ampicillin and $0.3 \mathrm{~g} . \mathrm{l}^{-1}(\mathrm{w} / \mathrm{v})$. A quantity of $25 \mathrm{~g}$ of each tempe sample was added to $225 \mathrm{ml} 0.85 \%$ (w/v) $\mathrm{NaCl}$, crushed and mixed to make a suspension prior to serial dilution. A $100 \mu \mathrm{l}$ aliquot of suspension was spread on PDA medium using the pour-plate method with two replications. Three-day-old fungal colonies were morphologically observed under the microscope to determine the types of fungi present.

Bacterial Analysis. Bacterial analysis was conducted on "non-bitter" and "bitter" fresh tempe as well as the soaking water taken from each tempe production process. The soaking water was sampled in three stages at 1,7 , and $14 \mathrm{~h}$ after the soybean soaking. A quantity of $25 \mathrm{~g}$ of each tempe sample was added to $225 \mathrm{ml} 0.85 \%$ (w/v) $\mathrm{NaCl}$ and then crushed using a stomacher for $1.5 \mathrm{~min}$. A $25 \mathrm{ml}$ aliquot of the soaking water was diluted with $225 \mathrm{ml} \mathrm{0.85 \%} \mathrm{(w/v)} \mathrm{NaCl}$ and then a serial dilution was made for each sample. From each dilution, a $100 \mu \mathrm{l}$ aliquot of suspension was spread on Plate Count Agar Media /PCA (Oxoid) to datermine the total cell number of mesophilic aerobic bacteria and spore-forming bacteria, and on Eosin Methylene Blue Agar/EMB (Difco) to reveal the total cell number of Enterobacteria. Spore-forming bacterial number was obtained by heating the sample to $85^{\circ} \mathrm{C}$ for $15 \mathrm{~min}$. Each test was done in replicate. Colonies were counted and observed for their morphological characteristics. The bacteria that grew on PCA, and the spore-forming bacteria, were tested for protease production using PCA-media enriched with $2 \%$ skimed milk. Test bacteria were spattered on the media and then incubated overnight at room temperature. Positive testing for protease-producing bacteria was carried out by directly observing the clear zones which formed around the colonies.

Identification Based on 16S rRNA Gene Sequence. Two types of dominant bacterial colonies on PCA media were identified through their 16S rRNA gene sequence. A $1.5 \mathrm{ml}$ aliquot of bacterial suspension wich had been grown for one night in PCA liquid media was centrifuged for 3 min at $10000 \mathrm{xg}$ (SORVALL ${ }^{\circledR}$ Pico, USA). The result an pellet was mixed with $200 \mu \mathrm{l} 0.85 \%$ (w/v) NaCl and the genomic DNA

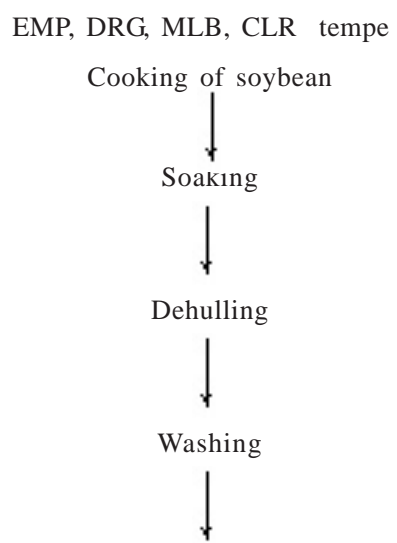

Mixing with inoculum

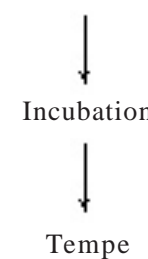

WJB tempe

Cooking of soybean
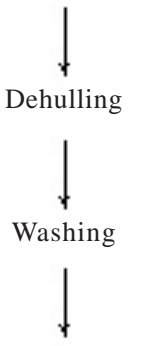

Soaking

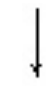

Cooking
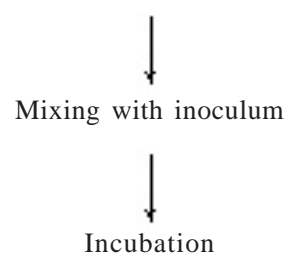

Tempe

Fig 1 Comparison of EMP, DRG, MLB, CLR, and WJB tempe manufacturing methods.

was extracted according to the procedure of a Genomic DNA Purification Kit (Fermentas, Vilnius, Lithuania).

The 16S rRNA gene was amplified employing a PCR machine (Perkin Elmer, Gene Amplification system 2400) using 63f primer (5'- CAGGCCTAACACATGCAAGTC) and 1387 r (5'- GGGCGGWT GTACAAGGC -3') (Marchesi et al. 1998). The reaction conditions (50 $\mu \mathrm{l})$ were as follows: $36 \mu \mathrm{l}$ $\mathrm{ddH}_{2} \mathrm{O}, 5 \mu \mathrm{l} 10 \mathrm{x}$ polymerase buffer, $1 \mu \mathrm{l}$ dNTPs, $1 \mu \mathrm{l}$ Taq DNA polymerase (Finnzymes, Espoo, Findland), $1 \mu$ l of $63 \mathrm{f}$ primer ( $5 \mathrm{pmol} / \mu \mathrm{l}), 1 \mu \mathrm{l}$ of $1387 \mathrm{r}$ primer $(5 \mathrm{pmol} / \mu \mathrm{l})$, and $3 \mu \mathrm{l}$ of sample DNA. The mixture was incubated in the PCR machine (Perkin Elmer, Gene Amp system 2400). The PCR protocol was as follows: initial denaturation at $94^{\circ} \mathrm{C}$ for $5 \mathrm{~min}$, denaturation at $92^{\circ} \mathrm{C}$ for $30 \mathrm{~s}$, annealing at $62^{\circ} \mathrm{C}$ for $30 \mathrm{~s}$, elongation at $72^{\circ} \mathrm{C}$ for $30 \mathrm{~s}$, and post PCR at $72^{\circ} \mathrm{C}$ for $7 \mathrm{~min}$. The PCR cycle was used 25 times. The PCR results were observed employing electrophoresis using $0.8 \%(\mathrm{w} / \mathrm{v})$ agarose gel. A DNA band of $1.3 \mathrm{~kb}$ was cut and then purified using the WIZARD ${ }^{\circledR} \mathrm{SV}$ Gel and Clean-Up System (Promega). Purified DNA was eluted with $35 \mu$ l nuclease-free water. DNA sequencing was carried out on an automatic DNA sequencer ABI PRISM 2400 (Perkin Elmer, USA). Resulting sequences were compared with DNA sequences available in the database of the European Bioinformatics Institute (EBI) using BLASTX 2.0 set to its default parameters.

\section{RESULTS}

Bitterness Sensory Test. Bitterness intensity scores of EMP, DRG, MLB, CLR, and WJB tempe were different. The test results of HSD at 5\% level showed that bitterness intensity 


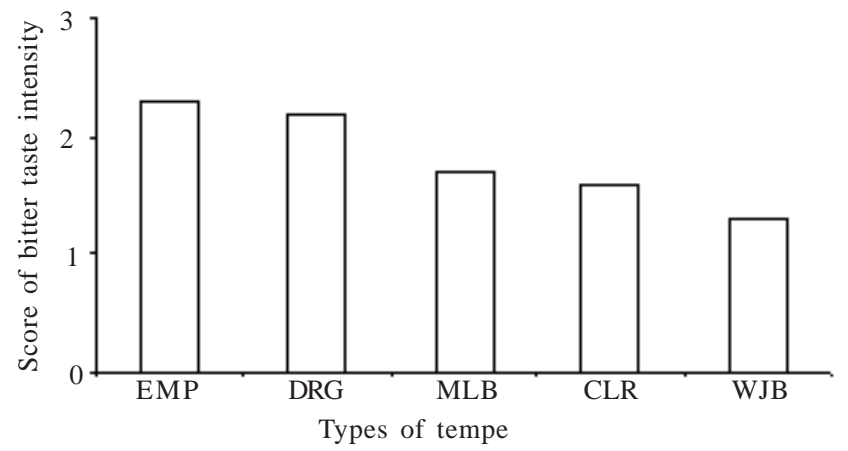

Fig 2 The scores of bitter taste intensity in a number of tempe types.

scores of the samples were categorized into three groups i.e. the highest scores EMP (2.3) and DRG (2.2), moderate scores MLB (1.7) and CLR (1.6) and the lowest score WJB (1.3). Scores followed by the same letter indicated that they were insignificantly different scores. Based on this bitterness sensory test, EMP that has the highest bitterness intensity score (2.3) was selected as representative of "bitter" tempe and WJB (1.3) as representative of "non-bitter" tempe.

Types of Fungi. Fungi that grew on tempe EMP were $R$. oligosporus and Mucor sp., each with a fungal abundance of $3.4 \times 10^{5} \mathrm{CFU} \mathrm{g}^{-1}$ and $3.5 \times 10^{3} \mathrm{CFU} \mathrm{g}^{-1}$ respectively. Fungi that grew on fresh tempe WJB were R. oligosporus, Mucor sp., and Geotrichum sp. with a fungal abundance of $3.8 \times 10^{5}$ $\mathrm{CFU} \mathrm{g}^{-1}, 4.8 \times 10^{3} \mathrm{CCFU} \mathrm{g}^{-1}$, and $<3.0 \times 10^{1} \mathrm{CFU} \mathrm{g}^{-1}$ respectively.

Bacterial Abundance. The number of Enterobacteria, spore-forming bacteria and proteolytic bacteria was found to be higher in soaking water and fresh tempe EMP compared to that of WJB (Table 1). Plating analysis showed that EMP soaking water contained a higher number of Enterobacteria, approximately $10^{3}-10^{4} \mathrm{CFU}$ $\mathrm{ml}^{-1}$, and spore-forming bacteria groups, $10^{2} \mathrm{CFU} \mathrm{ml} \mathrm{m}^{-1}$, compared to WJB. Similarly, the number of other bacteria groups in fresh EMP tempe was $10^{2} \mathrm{CFU} \mathrm{g}^{-1}$ higher than those in fresh WJB tempe. Based on morphological characteristics (Table 2), the bacteria that grew dominantly on PCA media from tempe EMP had morphological characteristics of type A, B, F, and I, while tempe WJB had type B, D, G, H, and I. Type I bacteria found in both tempe types has proteolytic activity. Enterobacteria found in EMP were dominated by

Table 1 Bacterial abundance in soak water 1,7, and 14 hours and fresh EMP and WJB tempe.

\begin{tabular}{lcccc}
\hline Kind of bacteria & $1 \mathrm{~h}$ & $7 \mathrm{~h}$ & $14 \mathrm{~h}$ & \multirow{2}{*}{$\begin{array}{c}\text { Fresh } \\
\text { tempe }\end{array}$} \\
\cline { 2 - 4 } EMP Tempe & \multicolumn{3}{c}{$\left(\mathrm{CFU} \mathrm{ml} \mathrm{I}^{-1}\right)$} \\
Enterobacteria & $3.1 \times 10^{6}$ & $7.7 \times 10^{7}$ & $3.3 \times 10^{8}$ & $1.1 \times 10^{8}$ \\
Spore-forming bacteria & $3.4 \times 10^{2}$ & $3.3 \times 10^{3}$ & $5.3 \times 10^{3}$ & $3.2 \times 10^{2}$ \\
Total bacteria (others) & $8.7 \times 10^{6}$ & $4.4 \times 10^{7}$ & $3.7 \times 10^{8}$ & $9.4 \times 10^{8}$
\end{tabular}

WJB Tempe

Enterobacteria

$6.1 \times 10^{2} 5.3 \times 10^{4} \quad 6.0 \times 10^{5} 4.2 \times 10^{5}$

Spore-forming bacteria $<3.0 \times 10^{1}<3.0 \times 10^{1}<3.0 \times 10^{1}<3.0 \times 10^{1}$ Total bacteria (others) $7.1 \times 10^{6} \quad 1.3 \times 10^{7} \quad 7.6 \times 10^{8} \quad 1.8 \times 10^{6}$ Spore-forming bacteria are proteolitic. bacteria with green metallic color (fecal) and other non-fecal bacteria, that were similar to the Enterobacteria found in WJB.

Bacteria Identification. Two types of dominant bacterial colonies on PCA media were identified through their 16S rRNA gene sequence. The strategy used to determine the bacteria was carried out based on their 16S rRNA gene sequence. Dominant bacteria on tempe EMP (Table 2) were Acetobacter indonesiensis, Klebsiella pneumoniae, Bacillus subtilis, and Flavobacterium sp., while dominants on tempe WJB were Klebsiella sp., Brevundimonas sp., Pseudomonas putida, Bacillus sp., and Acinetobacter sp. Bacillus, a group of proteolytic bacteria, was found in high abundance in the soaking water of EMP than WJB.

\section{DISCUSSION}

Fermentation is one of the technologies that have been used for a long time in food processing. One of the Indonesian traditional foods that is processed through fermentation is tempe. In tempe processing, soybean, microbes, and technology blend into one to produce tempe which is superior in characteristics compared to raw soybean.

Based on the bitterness sensory test, tempe CLR, DRG, MLB, EMP, and WJB have different bitterness intensity scores (Fig 2). Bitter taste was found in every sample but with different intensity. This was not caused by a

Table 2 The type of bacteria dominant in soak water and fresh tempe EMP and WJB grown on PCA medium

\begin{tabular}{|c|c|c|c|c|}
\hline Sample & $\begin{array}{l}\text { Dominant } \\
\text { colonies }\end{array}$ & $\begin{array}{l}\text { CFU ml-1 } \\
\text { CFU g }^{-1}\end{array}$ & Identities & $\begin{array}{c}\text { Similarity } \\
(\%)\end{array}$ \\
\hline
\end{tabular}

EMP tempeh

Soak water 1 Type A $5.5 \times 10^{6}$ Acetobacter indonesiensis 100 Type I $3.1 \times 10^{6}$ Bacillus subtilis.*

Soak water 2 Type B $3.7 \times 10^{7}$ Klebsiella pneumoniae Type I $6.6 \times 10^{6}$ Bacillus subtilis*

Soak water 3 Type B $3.7 \times 10^{8}$ Klebsiella pneumoniae Type I $4.7 \times 10^{5}-$

Fresh tempeh Type F $5.9 \times 10^{8}$ Flavobacterium sp. Type B $3.5 \times 10^{8}$ Klebsiella pneumoniae

WJB tempeh

Soak water 1 Type B $7.1 \times 10^{6}$ Klebsiella sp. Type I $3.3 \times 10^{1}$ Bacillus sp.*

$\begin{aligned} \text { Soak water } 2 & \text { Type B } 1.3 \times 10^{7} \text { Klebsiella sp. } \\ & \text { Type G } 3.5 \times 10^{3} \text { Brevundimonas sp }\end{aligned}$

$\begin{array}{lllll}\text { Soak water } 2 & \text { Type B } 1.3 \times 10^{7} \text { Klebsiella sp. } \\ & \text { Type G } 3.5 \times 10^{3} \text { Brevundimonas sp. }\end{array}$

Soak water 3 Type B $7.6 \times 10^{8}$ Type G $3.0 \times 10^{5}-$

Fresh tempeh Type D $1.7 \times 10^{6}$ Pseudomonas putida Type H $5.4 \times 10^{3}$ Acinetobacter sp.

Type A: globular, smooth periphery, mucous, curved, yellowish white, small; B: globular, smooth periphery, mucous, curved, white, small; D: globular, smooth periphery, mucous, curved, white, big; F: globular, not smooth periphery, mucous, curved, brownish white, big; G: globular, not smooth periphery, mucous, curved, white, medium; H: globular, smooth periphery, mucous, emerge, yellowish white, small; I: not uniform and spread out, mucous, plate shaped, white, big; -: not identified; *: poteolitic bacteria. 
soybean factor, because the same type of soybean was used in producing the tempe i.e. GCU, USA Soybean No. 1.

Sensory test results of the five kinds of tempe showed that the strongest bitterness intensity was found in EMP with the weakest in WJB (Fig 2). The EMP and WJB tempe were made by a different processing method. However, this research indicated that the difference in processing did not cause a significant differences in tempe bitterness intensity. This is supported by the results of laboratory tests, where tempe processing was conducted by using with EMP and WJB methods of processing (Fig 1). In this experiment, tempe was made with the same kinds of soybean, inoculum, and sterile water, but with different processing methods. The result of the sensory test of both tempe is shows that the bitterness scores were not significantly different, being 1.1 and 1.2 .

Tempe EMP and DRG were produced employing the same method as tempe MLB and CLR (Fig 1). However they had significantly different intensity scores (Fig 2). This result confirmed the result of Hartoyo (1994) which stated that the bitterness intensity of tempe could differ among producers eventhough they used the same raw material and processing method.

Sensory test results of the five kinds of tempe showed that the strongest bitterness intensity was found in EMP and the weakest in WJB (Fig 2). The inoculum used to produce both tempe types came from the same source, PT. AFI, Bandung, Indonesia. According to their fungal characteristics, the types of fungi in EMP and WJB were found to be similar both in quantity and types. These similarities can occur because both manufactures used the same source of inoculum. The difference in bitterness intensities of EMP and WJB could not come from the fungi because the sensory test results for both tempe products inoculated by the fungal inoculum from EMP and WJB did not show significantly different intensity scores (1.1 and 1.2 respectively).

The number of bacterial cells for EMP was generally higher than for WJB. Dominant bacteria found in soaking water and fresh tempe of EMP were Acetobacter indonesiensis, Klebsiella pneumoniae, Bacillus subtilis and Flavobacterium sp. In WJB the bacteria were Klebsiella sp. and Pseudomonas putida (similarity 99\%). Other than the number of bacteria, bacterial diversity in the food ecosystem is a very important factor to determine food quality because different microbes have different functions and these are absolutely important in establishing the conditions of the environment during the fermentation process (Scahwan 1998; Ampe et al. 2001; Randazzo et al. 2002). In food processing which includes a fermentation process, flavor is greatly influenced by the types of microorganisms involved.

The total cell population of Bacillus sp. found in EMP soaking water was higher than WJB (Table 2). Bacillus sp. has proteolytic activity. According to Omafuvbe et al. (2002), protease from different Bacillus sp. produce a different free amino acid content of soy-daddawa. A different free amino acid content cause the different sensory attributes soy-daddawa (Nigerian-fermented soyfood).
Soybean, as the raw material of tempe, contains around $40 \%$ protein from its dry weight. The protein consists of $11 \mathrm{~S}$ glycinin and $\alpha, \beta, \gamma$ conglycinin (Liu 1997). Hydrolysis of soybean $11 \mathrm{~S}$ glycinin by trypsin results in bitter peptides that have molecular weights of 2.4 to $3.5 \mathrm{KDa}$ (Kim et al. 2003). Furthermore Myong et al. (2004) reported that enzymatic hydrolysis of soybean protein resulted in a bitter taste because of the formation of peptides with molecular weights around 2 to $4 \mathrm{KDa}$.

Bitter taste in tempe can be caused by many factors, but result of this research indicated that the presence of bacteria involved during processing might be one factor that influences flavor formation, particularly the bitterness of tempe. This presumption is strengthened because the type of fungi present, methods used, and the raw material used did not affect bitterness intensity differences. Therefore, bacterial analyses which do not depend on culturable bacteria are needed to further support this observation i.e. it is the bacteria present during tempe processing which affects flavor formation.

\section{REFERENCES}

Ampe F, Sirvent A, Zakhia N. 2001. Dynamics of the microbial community responsible for traditional sour cassava starch fermentation studied by denaturing gradient gel electrophoresis and quantitative rRNA hybridization. Int J Food Microbiol 65:4554.

Broadbent JR, Barnes M, Brennand C, Strickland M, Houck K, Johnson ME, Steele JL. 2002. Contribution of Lactococcus lactis cell envelope proteinase specificity to peptide accumulation and bitterness in reduced-fat cheddar cheese. Appl Environ Microbiol 68:1778-1785.

Hagedorn S, Kaphammer B. 1994. Microbial biocatalysis in the generation of flavor and fragrance chemicals. Ann Rev Microbiol 48:773-800.

Hartoyo LK. 1994. Usaha mengurangi rasa pahit pada tepung tempe dari bahan mentah tempe kedelai produksi beberapa pengrajin tempe di Bogor [Thesis]. Bogor: Institut Pertanian Bogor.

Keuth S, Bisping B. 1994. Vitamin $B_{12}$ production by Citrobacter freundii or Klebsiella pneumoniae during tempe fermentation and proof of enterotoxin absence by PCR. J Appl Environ Microbiol 60:1495-1499.

Kim MR, Kawamura Y, Lee CH. 2003. Isolation and identification of bitter peptides of tryptic hydrolysate of soybean 11S glycinin by reverse-phase high-performance liquid chromatography. $J$ Food Sci 68:2416-2422.

Klus K, Borger-Papendorf G, Barz W. 1993. Formation of 6,7,4 tryhidroxyisoflavone (factor 2) from soybean seed isoflavone by bacteria isolated from tempe. J Phytochem 34:979-981.

Liu K. 1997. Soybeans: Chemistry, Technology, and Utilization. Ney York: International Thomson Publ.

Marchesi JR, Sato T, Weightman AJ, Martin TA, Fry JC, Hiom SJ, Wade WG. 1998. Design and evaluation of useful bacteriumspecific PCR primers that amplify genes coding for bacterial $16 \mathrm{~S}$ rRNA. Appl Environ Microbiol 64:795-799.

Meilgaard M, Civille GV, Carr BT. 1999. Sensory Evaluation Techniques. $3^{\text {th }}$ Ed. Boca Raton: CRC Pr.

Myong JC, Unklesbay N, Hsieh FH, Clarke AD. 2004. Hydrophobicity of bitter peptides from soy protein hydrolysates. J Agric Food Chem 52:5895-5901.

Omafuvbe BO, Abiose SH, Shonukan OO. 2002. Fermentation of soybean (Glycine max) for soy-daddawa production by starter cultures of Bacillus. J Food Microbiol 19:561-566.

Randazzo CL, Toriani S, Akkermans DADL, de Vos WM, Vaughan EE. 2002. Diversity, dynamics, and activity of bacterial communities during production of an artisanal sisilian cheese as evaluated by $16 \mathrm{~S}$ rRNA analysis. Appl Environ Microbiol 68:1882- 1892 . 
Rodas AM, Ferrer S, Pardo I. 2003. 16S-ARDRA: a tool for identification of lactic acid bacteria isolated from grape must and wine. J Sys Appl Microbiol 26:412-422.

Schawan RF. 1998. Cocoa fermentation conducted with a defined microbial cocktail inoculum. Appl Environ Microbiol 64:14771483.
Stahnke LH. 1994. Aroma component from dried sausages fermented with Stapylococcus xylosus. J Meat Sci 38:39-53. 